\title{
Effective Legal Protection against the Excessive Length of Administrative Decision-Making: The Cases of Slovenia and Croatia
}

\author{
Tina Sever, Ana Đanić, Polonca Kovač $\check{c}^{1}$
}

\begin{abstract}
In administrative matters, the parties usually have a right of access to the court and to a fair trial within a reasonable time limit, as defined by constitutions, only after the exhaustion of appeals. Judicial review is performed in a majority of states by a specialised administrative court in accordance with Articles 6 and 13 of the European Convention on Human Rights (ECHR). Based on a comparative research analysis of supranational and national normative law and European Court of $\mathrm{Hu}-$ man Rights (ECtHR) case law, this paper provides insight into the extent to which administrative matters can be reviewed in administrative disputes as well as into the legal remedies available to the parties, especially when the authorities violate time limits, focusing on the compliance of the regulation in Slovenia and Croatia with the ECHR standards. The paper also illustrates a comparative perspective of regulation in other European countries, namely Austria and Estonia. Our findings show the importance of the awareness of the necessary interplay between acts on administrative procedure and acts on administrative disputes for an effective realisation of the parties' rights and the public interest, with administrative justice ensuring a safety net by guaranteeing an effective legal remedy.
\end{abstract}

Key words:

administrative matters, administrative procedure, administrative disputes, administrative silence, effectiveness, European Convention on Human Rights, reasonable time, Slovenia, Croatia.

1 Tina Sever, PhD, Teaching Assistant; Polonca Kovač, PhD, Associate Professor, University of Ljubljana, Faculty of Administration, Ljubljana, Slovenia; Ana Đanić, Teaching Assistant, J. J. Strossmayer University, Faculty of Law, Osijek, Croatia. 


\section{Introduction}

The purpose of the legal regulation and conduct of administrative procedures (APs) is to resolve conflicts between public and private interests, with an emphasis on restricting absolute power and encouraging the efficiency of public policies arising within APs. With the development of the rule of law, AP and administrative-judicial control of individual administrative acts evolved into a basic procedural tool intended to protect fundamental human rights and other rights of the parties. In accordance with Article 6 of the European Convention on Human Rights (ECHR), everyone is entitled to a fair and public hearing within reasonable time, in administrative matters as well. ${ }^{2}$ Furthermore, Article 13 of the ECHR requires an effective remedy at the national level for all the rights ensured by the ECHR (more on the content and impact of the ECHR in Auburn et al. 2013, 43, etc.).

The Republic of Slovenia and the Republic of Croatia have a common historical background, being legal successors to the former Yugoslavia and adopting much of its regulation after becoming independent in 1991. Since they used to be part of a common former state and are again under the same supranational authority, with Slovenia joining the EU in 2004 and Croatia following in July 2013, a comparative normative research was carried out, focusing on the effectiveness of judicial review in administrative matters with regard to timely decision-making. The paper analyses the countries' profiles and puts them into the context of comparative approaches as followed by some other European countries, such as Austria and Estonia. Based on the fact that Slovenia and Croatia have a similar geo-political position and are both bound by common EU regulation and contracting parties to the $\mathrm{ECHR}^{3}$, we analysed their general laws on AP (APA) and administrative dispute/s (ADA), which are decisive for administrative decision-making in light of Articles 6 and 13 of the ECHR and their national constitutions of 1991, namely the following:

- Zakon o splošnem upravnem postopku, the Slovene APA (OG RS ${ }^{4}$ No. 80/99 and amendments);

- Zakon o upravnem sporu, the Slovene ADA (OG RS No. 105/2006 and amendments);

2 Since the ECHR is a living instrument, the European Court of Human Rights (ECtHR) adopted a broad definition of civil matters as defined by Article 6, including also public (administrative) matters in national law, such as: issuing licenses/concessions, permits to perform certain activities (for example, authorisation to run a medical clinic), building permits; expropriation; denationalisation; consolidation; social-security rights, etc. (see König v. Germany, No. 6232/73, 28 June 1978; Le Compte, Van Leuven and De Meyer v. Belgium, No. 6878/75, 7238/75, 23 June 1981; Sporrong and Lönnroth v. Sweden, No. 7151/75, 7152/75, 23 September 1982, etc.). The ECtHR similarly includes in the concept of criminal matters also disciplinary measures; tax penalties; misdemeanours, etc. (see Decision OAO Neftyanaya Kompaniya Yukos v. Russia, No. 14902/04, 29 January 2009; Öztürk v. Germany, No. 8544/79, 21 February 1984, etc.).

3 Slovenia ratified it in 1994 and Croatia in 1997.

4 Official Gazette of the Republic of Slovenia. 
- Zakon o općem upravnom postupku, the Croatian APA (OG RC ${ }^{5}$ No. 47/09);

- Zakon o upravnim sporovima, the Croatian ADA (OG RC No. 20/10, 143/12, 152/14).

Since justice delayed can lead to justice denied, it is important that all instances be conducted within reasonable time, which is one of the fundamental principles of good administration and good governance. ${ }^{6}$ As derives from the European Court of Human Rights (ECtHR) case law, when establishing the relevant period and its (un)reasonable length in administrative matters, the period to be taken into consideration starts when the dispute arises, i.e. upon the lodging of an appeal at the second instance, if that is a prerequisite to filing a lawsuit against an administrative act. ${ }^{7}$

In APs, the parties in the respective countries pursue rights of a positive nature, being dependent on the decision-making of the administrative authorities. Contrary to civil matters, the parties need to first enforce their rights before the administrative authority of the first instance; later on, they can file an appeal at the second instance. The exhaustion of the appeal is a procedural prerequisite to filing a lawsuit, meaning that some time will elapse before receiving a final and enforceable act by which to exercise rights. In administrative matters, the parties have a right of access to the court and to a fair trial within a reasonable time limit, as defined already by constitutions, which envisage a judicial procedure before a specialised administrative court (the principle of the separation of powers). Only in limited cases can the competent administrative court, in both Slovenia and Croatia, decide on the merits to efficiently protect the parties' rights; otherwise the decisions will only be abolished and returned to the administrative authority to decide again.

Throughout Europe, we can nowadays, according to Woehrling (2009, 4-5), distinguish three judicial review families: a) common-law countries (despite the inclusion of judicial review of administration in regular courts, a certain degree of specialisation is needed due to the increasing complexity of regulation); b) countries inspired by the French model, following objective legality and extending locus standi (meaning that also legitimate interest suffices), and c) countries influenced by the German tradition (control is based on the concept of subjective rights: protection of the individual against the administration; for more, see Woehrling 2009, 4-5, and $2014,23-24)$. As exposed by Woehrling $(2014,23)$, the majority of the new democracies in Central and Eastern Europe were inspired by the German model, which also applies to the Slovene and Croatian administrative justice systems.

5 Official Gazette of the Republic of Croatia.

6 See Venice Commission - European Commission for Democracy through Law, 2011. Stocktaking on the Notions of "Good Governance" and "Good Administration", Study No. 470/2008, CDLAD(2001)009, 17-18. Cf. Sever et al. 2014, 249-275.

7 See Božić v. Croatia, No. 22457/02, 29 June 2006 (para. 26). Janssen v. Germany, No. 23959/94, 20 December 2001 (para. 40). König v. Germany, No. 6232/73, 28 June 1978 (para. 98). 
Slovenia has a slightly longer tradition with regard to its new administrative dispute regulation (which entered into force in January 2007); in Croatia, on the other hand, the new law entered into force in 2012, hence our research on whether the institutions designated to accelerate proceedings and lower the costs comply with the European standards on decision-making within a reasonable time limit and ensuring an effective legal remedy as fundamental human rights.

The research is aimed at identifying the trends regarding the regulation and implementation of administrative decision-making in both countries, giving short insight into the regulation of selected European countries (Austria and Estonia) in order to establish possible good practices and make further recommendations based on the obtained results. The main methods used include normative, comparative, and historical methods, an analysis of the ECtHR case law regarding the respective countries and connected cases, and finally the presentation of an axiological-deontological evaluation of the state of play and the necessary trends in these countries.

\section{The legal protection of issuing decisions within reasonable time in administrative matters}

\subsection{Timely decision-making in administrative matters in Slovenia}

The subject of administrative relations is decision-making in an administrative matter, and the relations are established, changed, or abolished through an AP. In the event of a violation of procedural or substantive law or deficiencies in establishing the facts of the case, the parties are entitled to legal remedies already during an AP, upon which the Executive decides (with appeal being the only ordinary legal remedy in addition to five extraordinary legal remedies). Subsequently, in accordance with the ECHR and Council of Europe recommendations, administrative acts are subject to judicial review in order to ensure the legality and protection of human rights. In accordance with Article 23 of the Slovene Constitution, everyone is entitled to judicial review without undue delay by an independent, impartial court established by law. Administrative acts are subject to judicial review in an administrative dispute in accordance with Articles 120 and 157 of the Slovene Constitution. Administrative disputes are regulated by the Slovene ADA. The Slovene administrative justice is a mixture of objective and subjective models, with the latter prevailing. ${ }^{8}$ As derives from the constitutional principle of the separation of powers, the main function of an administrative dispute is the supervision of the performance of the Executive; only in limited cases will the court decide on the merits (a dispute of full jurisdiction). Namely, administrative authorities employ public officials specialised in specific public domains, thus ensuring an efficient performance of

8 See Decision of Constitutional Court, No. U-I-57/06-28, 29 March 2007 (point 38). Grafenauer and Breznik 2009, 656-657. 
public duties (cf. Androjna and Kerševan 2006, 674). When conducting APs, their role is twofold, i.e. protecting the public interest and at the same time looking after the rights of the weaker party. Consequently, the parties should receive a decision on the merits in due time by the competent first-instance administrative authority. In case of irregularities, the parties have the right to file a complaint to the competent second-instance administrative authority. In accordance with the principle of the separation of powers, administrative and judicial procedures should function complementarily, with the common goal to issue a correct decision. Namely, administrative decision-making should be efficient and lawful and reduce the courts' caseload (cf. Woehrling 2014, 21-22, 31-32). Therefore, administrative dispute should be reserved only for the gravest errors. In such a case, if all conditions are fulfilled (request of the party, relevant data and nature of the matter, etc.) the court should reconsider to decide on the merits. After all, the "ultimate goal" of the administrative system is to decide on the parties' rights and obligations with respect to the public interest within reasonable time. If the procedure has already reached the court, the party seeks some kind of satisfaction, preferably a decision. Therefore, only returning the case to lower administrative authorities, with instructions on how to correct the AP, definitely prolongs the overall duration and postpones the parties' possibility to acquire and exercise their substantive rights. Finally, in our opinion, the court's duty is primarily to decide on the legality of administrative acts. In this regard, the possibility to decide on the merits should not be avoided, but used whenever possible.

Administrative disputes are independent judicial procedures; however, in certain circumstances, they can "substitute" for the parties' appeal against first-instance administrative decisions (when an appeal is excluded). The parties can file a lawsuit before an administrative court within 30 days of the service of a final administrative decision, by citing all the reasons possible in an appeal (such as incorrect application of the law, a material violation of procedural provisions and incomplete finding of facts). ${ }^{9}$ The administrative court decides, as a rule, in councils consisting of three judges, and only exceptionally a single judge decides alone. The exhaustion of the right to an administrative dispute is a prerequisite for a constitutional complaint.

The Slovene APA sets general instructive time limits for the issuance of an administrative decision: two months in special declaratory proceedings and one month in summary proceedings (see Article 222 of the APA). If proceedings are suspended, time limits do not run. In the event of administrative silence, the Slovene APA provides two possibilities: the transfer of competence to the second instance and the parties' right to appeal (Articles 18 and 222). One deficiency as regards such transfer is that it is obligatory only when life, health, the natural environment or property are in danger. Otherwise, it is left to the discretion

9 Decision of Constitutional Court, No. U-I-98/07, 12 June 2008 (point 14). Decision of Constitutional Court, No. U-I-219/03, 1 December 2005. 
of the authority of the second instance to assume competence. In the event of a time limit violation, the authority of the second instance first warns the head of the authority of the first instance and sets up a new instructive time limit. If afterwards the decision is still not issued, the authority of the second instance can assume competence (the decision thereon is left to its discretion). The parties, however, cannot demand such transfer of competence. In the event of a delay, a party's claim is deemed to be dismissed (a negative fiction). After the expiry of the time limit, the party is entitled to file an appeal anytime until the issuance of the decision. The authority of the second instance checks whether the reasons for the delay were justified or not. If the reasons were not justified, it can assume competence for the matter and decide on the merits within two months (only an instructive time limit). If the authority of the first instance had justified reasons for delay or when the reasons were on the party's side, the authority of the second instance prolongs the time limit for the issuance of a decision by the period of the delay (but not longer than one month). If the matter is not resolved by the prolonged time limit and the party files a new appeal, then the authority of the second instance is obliged to assume competence and decide on the merits.

The main shortcoming of the analysed regulation is that it puts a large proportion of the burden on the parties, meaning that they have to be active themselves to receive specific rights in the field of administrative law; otherwise, the procedures can be stalled for years. We have to bear in mind that in APs, the parties are laypersons, and legal representation is not obligatory. With a negative fiction defined by law, the violation of time limits in administrative matters is legalised, even though it is evidently a question of malpractice, infringing the principles of good administration. The latter is more than just about the legality of performance, and administrative decision-making should also pursue quality and efficiency. We find the regulation to be too much "in favour" of the first-instance authority, leaving most of the responsibility to the parties, therefore we would prefer a higher level of responsibility to be given to the second-instance authority and its substantive decision-making in the event of delays at the first instance.

Subsequently, if the authority at the second instance fails to issue a decision by the prescribed time limit, the parties are entitled to an administrative dispute (see Articles 5 and 28 of the ADA), but only after lodging an urgent request with the second instance that a decision be issued within the following seven days. Only when administrative silence is unjustified and the lawsuit itself is justifiable can the court decide on the merits, providing that the following conditions are fulfilled (cf. Androjna and Kerševan 2006, 756-757; cf. also Article 65/3 of the Slovene ADA): there has been a request from the plaintiff for a decision on the merits; substantive decision-making is in accordance with the nature of the matter; and the court has the necessary data or establishes the relevant facts by itself at the oral hearing (in the last 3 years only $0.20 \%$ of the court's decisions were on the merits, see Table 1 ). If deciding on the merits is not possible, the court instructs the administrative au- 
thority to issue an administrative decision. The administrative authority can again decide not to issue a decision, placing the burden of complaining on the party once more.

In accordance with the principle of subsidiarity (Article 3 of the Slovene APA), sector-specific legislation can also regulate a positive fiction in the event of administrative silence. This trend is also encouraged by EU Directive 2006/123/EC of the European Parliament and the Council of 12 December 2006 on services in the internal market. ${ }^{10}$ The Slovene sector-specific legislation foresees such possibility for certain rights, however there are problems with the finality and executability of the decision since there is no physical document and an unclear date of entry into effect. Therefore, additional evidence has to be provided, such as the confirmation of the receipt of the request, etc. (Kovač 2012).

It has to be concluded that in the event of administrative silence, legal remedies cannot prevent the cases being returned to lower authorities and repeating the whole procedure, placing most of the burden on the party which has to lodge a new appeal or lawsuit or the procedures can be stalled for a long period of time (also a few years). Moreover, administrative-silence remedies, as currently regulated, cannot compensate for delays that have already occurred. The efficiency of such regulation is therefore under question, also in light of the very low number of such appeals in practice. ${ }^{11}$ Furthermore, the Slovene ADA defines three years as the ultimate time limit for the issuance of a final administrative act, regardless of the use of legal remedies. This rule was set to prevent the cases from being returned to lower instances, although we think that three years is a rather long period for the parties to receive enforceable rights. Therefore, the "reasonableness" of such a time limit is in question. Namely, in our opinion, it allows postponing the decision-making and can still lead to a "ping-pong" effect between administrative authorities. This period, if prescribed by law, should be shorter, e.g. six months to a maximum of one year (except when sector-specific law defines longer time limits to decide on specific matters). Furthermore, the defined length should depend on the importance and complexity of the matter.

Another "remedy" for the party in the event of delays in APs is the possibility to inform the administrative inspection service of the violation of time limits. The number of violations of instructive time limits that have been found is among the highest compared to other violations of the APA rules. The administrative inspection service will start a procedure ex officio if a petition is well founded. Unfortunately, the administrative inspection service does not have many powers to influence the course of proceedings, except to give instructions to issue decisions within

10 Official Journal of the European Union L 376/36, 27 December 2006.

11 See Kovač 2012; cf. Table 1. The two main reasons for the low use of this remedy are unawareness of the possibility and viewing it as senseless, giving preference to addressing the first instance directly. 


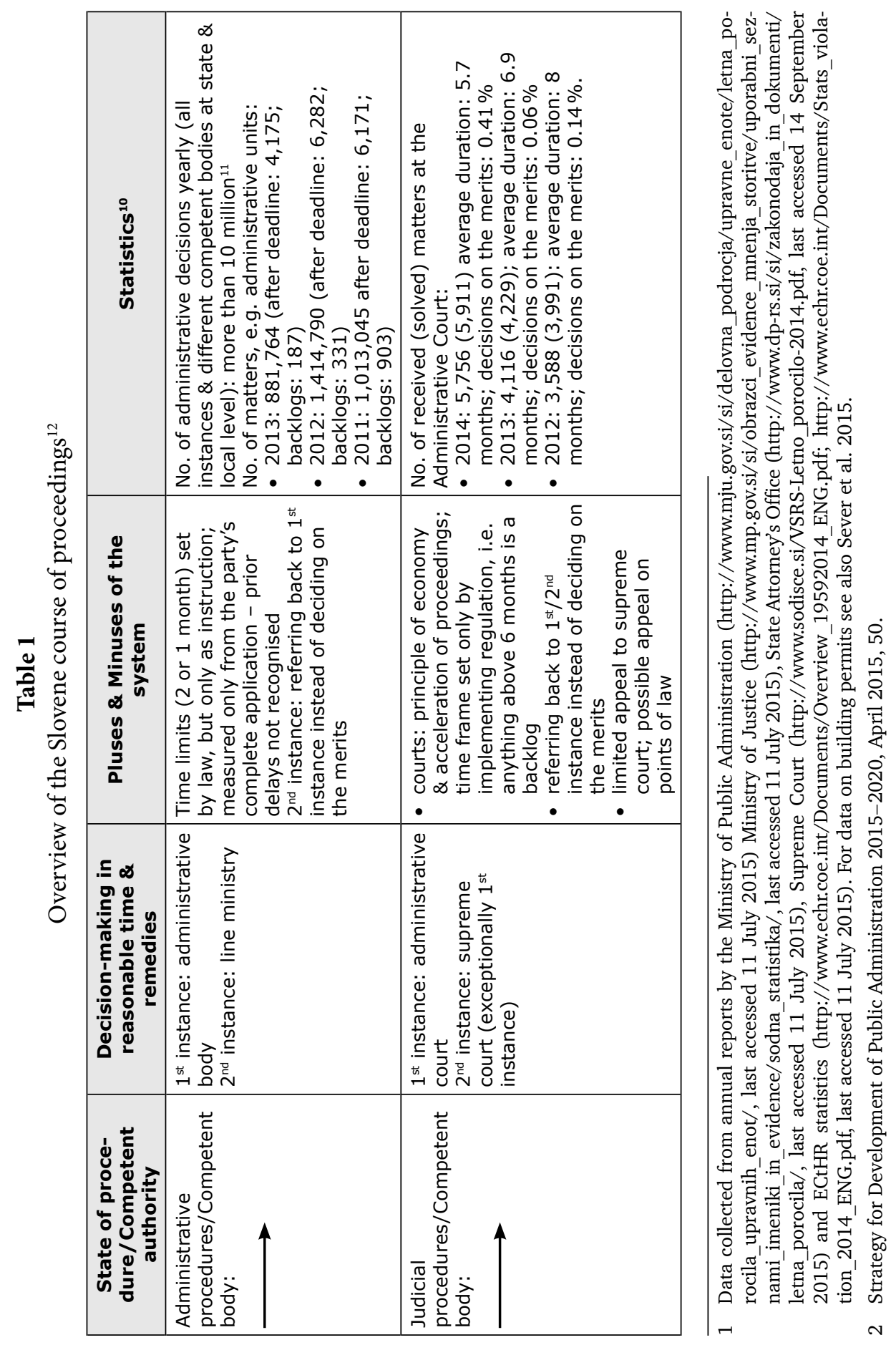




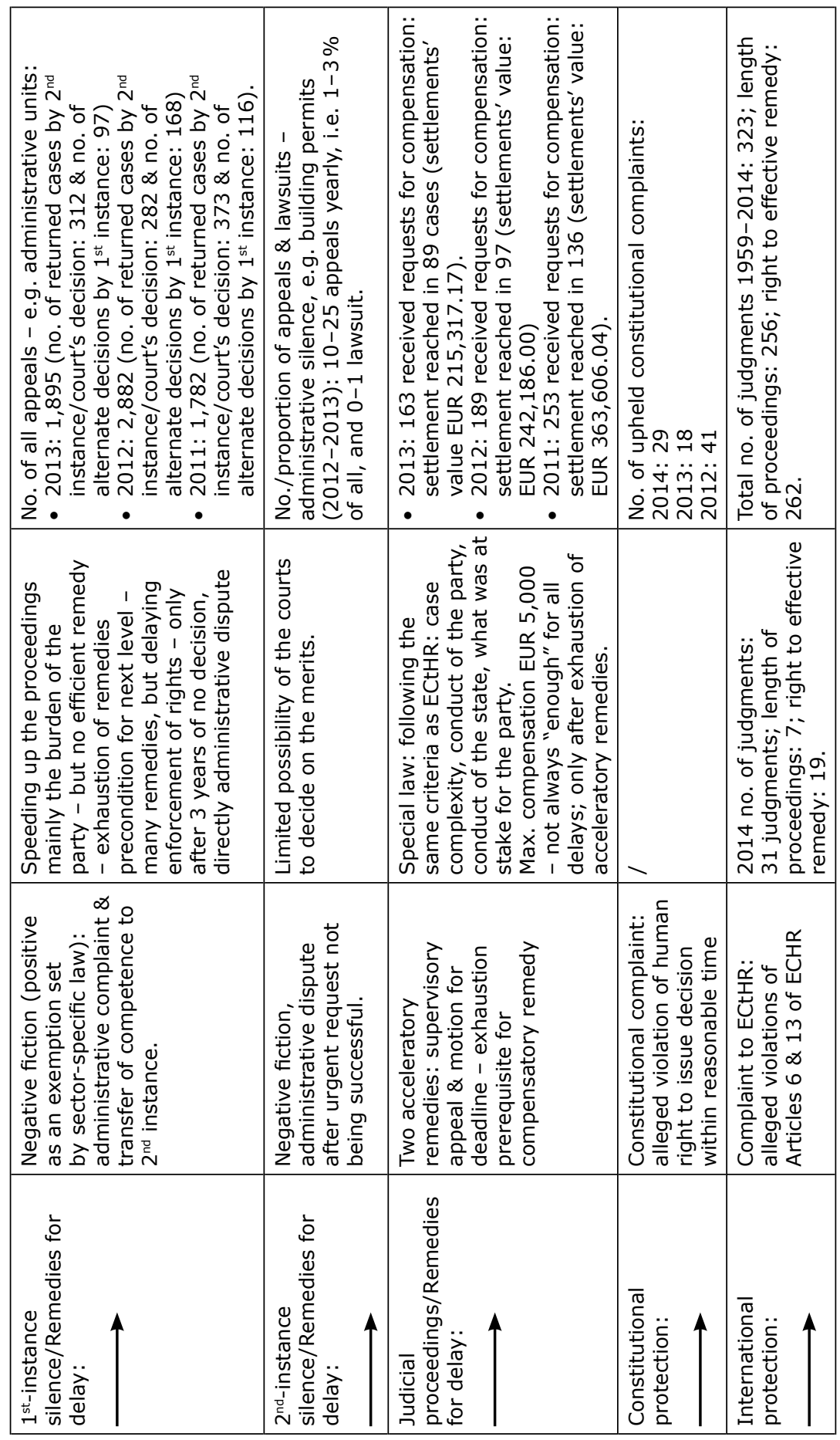


reasonable time and the possibility to instruct officials to pass the professional exam on AP. Finally, there is also the possibility to file an initiative to the ombudsman that has the power to put pressure on the competent authority to issue decisions within due time. In light of this rather narrow room for manoeuvre of the parties in terms of possible incentives to speed up proceedings, the need to respect the existing rules on timely decision-making is all the more important.

Judicial procedures also have certain deficiencies that can affect the right to a fair trial within a reasonable time limit. For example, the Slovene ADA does not define the time limit for issuing a judgment. Article 22 of the ADA provides for a mutatis mutandis application of the Civil Procedure Act (CPA) $)^{12}$ also in administrative disputes. The CPA introduces the general principle of the economy and the acceleration of proceedings, which is valid also for administrative disputes, but does not determine the time limit for issuing a judgment. The Slovene ADA and CPA are more specific only when the court carries out an oral hearing, in which case the judgment is declared immediately after the oral hearing is concluded. The exact time limits are determined in certain administrative fields by sector-specific legislation (for example, the International Protection $\mathrm{Act}^{13}$ ). Moreover, the implementing regulation "Court Rules"14 determines the maximum time frame that may not be exceeded; otherwise, the judicial procedure is deemed overdue. For administrative disputes, the maximum time limit is six months. According to the annual reports on the Administrative Court's caseload, in 2012 the Court managed to solve more cases (altogether 3,991 ) than it received $(3,588)$, which shows a positive trend; however, the procedures before the Administrative Court in 2012 lasted on average almost 8 months, which - in accordance with the Court Rules - is overdue. In 2013, the Court continued the positive trend of resolving more cases (altogether 4,229) than it received $(4,116)$, but the procedures lasted on average 6.9 months, meaning they still took longer than the maximum time limit set by the Court Rules (i.e. 6 months). ${ }^{15}$ As agreed between the Government of the Republic of Slovenia and the Supreme Court in June 2013, the average time of procedures before the Administrative Court should be reduced to a maximum of 6 months by 1 June 2014. Data for the period from July 2013 to June 2014 still showed an average actual time of procedures of 6.8 months, but improved for the period from April 2014 to March 2015

12 OG RS No. 26/1999 and amendments.

13 OG RS No. 111/2007 and amendments. For example pursuant to Article 51 (paragraph 5) of IPA, the court must decide in three (3) working days.

14 OG RS No. 17/1995 and amendments. See Article 50 of the Court Rules.

15 See statistics at http://www.sodisce.si/sodna_uprava/statistika_in_letna_porocila/poslovanje sodstva/ and http://www.sodisce.si/mma_bin.php?static_id $=20140213133551$ (last accessed 24 January 2015). 
with the average actual time of 5.8 months (see Table 2, cf. Table 1). ${ }^{16}$ With the aim of accelerating judicial procedures, in 2006 the Slovene ADA limited the right to appeal against a first-instance judgment. Namely, the right to judicial review in administrative matters is meant as supervision of the administrative authorities by the court and not as a way to check the decisions of judges. The right to appeal in judicial proceedings is, in accordance with Article 73 of the Slovene ADA, limited only to cases when the court itself examined the facts of the dispute and issued a different decision or when it decided on the legality of acts prejudicing human rights (see Articles 4 and 66 of the Slovene ADA). Subsequently, the parties are also entitled to two extraordinary legal remedies under the jurisdiction of the Supreme Court: reopening of the case and revision. Procedures before the Supreme Court (namely, the department for administrative matters) are faster than at the first instance and lasted on average 4.7 months in 2012 and 3.5 months in 2013, also showing a positive trend as regards resolving more cases than it received (e.g. in 2013 the Supreme Court received 954 cases and solved 992 cases). ${ }^{17}$ However, the overall duration of procedures is still too long (bearing in mind the two instances in APs and possibly two instances before the courts).

Table 2

Average actual time of solving important matters

\begin{tabular}{|l|c|c|}
\hline \multicolumn{1}{|c|}{ Court } & $\begin{array}{c}\text { No. of months } \\
\text { for the period: } \\
\mathbf{1 . 4 . 2 0 1 4 - 3 1 . 3 . 2 0 1 5}\end{array}$ & $\begin{array}{c}\text { No. of months } \\
\text { for the period: } \\
\mathbf{1 . 7 . 2 0 1 4 - 3 0 . 6 . 2 0 1 5}\end{array}$ \\
\hline Supreme Court & 6 & 6 \\
\hline Higher Court & 2.7 & 2.6 \\
\hline District Court & 12.4 & 12.4 \\
\hline Local Court & 7.5 & 7.5 \\
\hline Administrative Court & 5.8 & 5.8 \\
\hline Higher Labour \& Social Court & 3.9 & 4 \\
\hline Labour \& Social Court & 15.9 & 14.1 \\
\hline
\end{tabular}

Source: http://www.sodisce.si/sodna_uprava/statistika_in_letna_porocila/poslovanje_sodstva/ (last accessed 14 September 2015)

The problem of court backlogs in Slovenia was already assessed by the ECtHR in 2005, when Slovenia was convicted due to the excessive length of proceedings in

16 See the agreement at http://www.mp.gov.si/fileadmin/mp.gov.si/pageuploads/mp.gov.si/ PDF/130604_Zaveza.pdf (last accessed 24 January 2015). For data on actual average times, see http://www.sodisce.si/sodna_uprava/statistika_in_letna_porocila/poslovanje_sodstva/ and

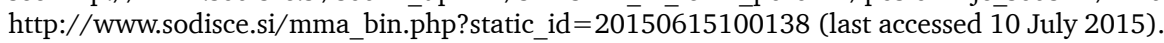

17 See annual reports of the Supreme Court at http://www.sodisce.si/sodna_uprava/statistika_in letna_porocila/ (last accessed 14 September 2015). 
a pilot judgment (the case of Lukenda v. Slovenia, No. 23032/02, 6 October 2005). The ECtHR established the existence of a systemic problem in the judicial system and violations of Articles $6 ₫ 1$ (the right to a fair hearing within reasonable time) and 13 of the ECHR (the right to an effective remedy). Slovenia improved the system by ensuring more resources (especially professional assistants to the judges) within the "Lukenda project" (2005-2014); more effective case management and monitoring of resolved matters by departments, judges; introducing a higher level of informatisation of procedures, etc. Beside the organisational, managerial and technical approaches, Slovenia also decided to introduce new legal remedies and in 2006 launched the Protection of the Right to a Trial without Undue Delay Act (PRTUDA), which has been in force since 1 January 2007. With this Act, the procedural right to decision-making within reasonable time also became a substantive right (cf. Galligan et al. 1998, 29). The main purpose of PRTUDA is to establish violations of the right to a trial without undue delay and the awarding of appropriate satisfaction. In the event of delays in court procedures, the parties are entitled to use two acceleratory remedies, first a supervisory appeal and then a motion for a deadline (the exhaustion of the supervisory appeal is a prerequisite for a motion for a deadline). The exhaustion of the two is a prerequisite for the compensatory remedy (i.e. monetary compensation, a statement from the state attorney and publication of the judgment). The new system introduced by PRTUDA is quite effective, following the same criteria as ECtHR case law when estimating the reasonableness of the length of proceedings, namely: the complexity of the case, the conduct of the party and the conduct of the state, as well as what was at stake for the party (see Article 4 of PRTUDA). However, certain problems still arise, such as the obligatory exhaustion of acceleratory remedies in order to be entitled to a compensatory remedy, the obligation to submit a proposal for settlement within nine months from service of the final judgment and the determination of the highest possible amount of monetary compensation already by PRTUDA (i.e. EUR 5,000) (see the ECtHR judgment W. v. Slovenia, No. 24125/06, 23 January 2014). In the last three years, Slovenia was still convicted due to a violation of the right to a fair trial within reasonable time and non-effective remedies (see the ECtHR statistics; see Table 1). Since in administrative matters two/three instances are already possible, the new remedies under PRTUDA can mean an additional burden for the parties and a delay in the enforcement of their rights.

\subsection{Timely decision-making in administrative matters in Croatia}

In Croatia, administrative dispute was finally harmonised with the developed European procedural standards, fundamental legislative principles and conventional 
guarantees by the adoption of the new ADA in 2010. ${ }^{18}$ The new ADA broadens the matter of the administrative dispute and ensures legal protection with every AP (Article 3 of the ADA). An important novelty is the introduction of the objective administrative dispute and general acts being put under the jurisdiction of the High Administrative Court (see Table 3).

Croatia "caught up" in matters that refer to Article 6 of the ECHR, ${ }^{19}$ whereby it is obligated to organise oral hearings before reaching decisions on administrative disputes in public sessions. The ECtHR insisted that changes be made as part of the reform and that oral hearings be introduced in disputes of full jurisdiction whereby the court itself determines the factual state by analysing the evidence; as well as to add an additional instance to the administrative courts and possible surveillance over the decisions reached by the first-instance Administrative Court. First, both the administrative procedure and the Administrative Court had to undergo extensive reforms in order to allow for balance in making the procedures faster and simpler, while at the same time efficiently providing for the protection of both citizens and the public interest. By doing so, the basic guarantee for the protection of the fundamental human rights and freedoms of the citizens was ensured all within the framework of modern administrative courts. At the same time, confidence in the system and institutions continues to grow; the basic values of the legislative order are spreading widely; support is being given to the rule of law and legal safety; and public interests are being protected. The court jurisdiction and composition (Article 14 of the ADA and 7 of the Law on Courts (LC)) for administrative disputes is determined such that individual judges decide at the first-instance administrative

18 OG RC No. 20/10. Until 2010, the Croatian model and the organisation of the Administrative Court was criticised for its numerous disadvantages with the aim of imposing/"demanding" the entire model to be modernised and harmonised with European standards. By doing so, emphasis was put on the concept of accepting the European legal/administrative standards and guarantees established by the ECHR and the acquis communautaire, while at the same time approaching the European model of the judicial review of administration (more in Koprić 2006, 58). Until the ratification of the ECHR in Croatia in 1997, there were no developed rules within the legal system that protected citizens from the stalling of judicial processes (Šikić 2009, 336). See also Koprić 2014, 10-12.

19 The Constitutional Court of the Republic of Croatia formed its decision No. U-I-745/1999, 8 November 2000, on whether or not the Administrative Court can be referred to as the High Court by referring to Article 6, Paragraph 1 of the ECHR. The decision directly affected the Constitution of the Republic of Croatia as regards amending Article 29 in 2000. Article 29, Paragraph 1, of the Constitution of the Republic of Croatia (55/90, 135/97, 8/98, 113/00, 124/00, 28/01, 41/01, 55/01, 76/10, 85/10, 05/14): "Everyone is entitled to have their rights and obligations as well as possible allegations or felony accusations determined in a timely and just manner by a legitimate, independent, and unbiased court." Up until then, regulations prescribing the timely resolution of legal matters did not exist within the Constitution. More in Omejec 2006, 10-12. See also Article 4 Paragraph 1 of the LC (OG RC No. 28/13, 33/15, 82/15). 
courts, while at the High Administrative Court three judges decide. ${ }^{20}$ The German example shows that an individual judge at the first-instance court can resolve approximately $80 \%$ of the cases (Reforma sustava upravnog sudovanja u Hrvatskoj $2008,573)$. However, we find that this legislative solution under the "pressure" and "pretence" of enhancing efficiency was actually a step backwards (Rostaš-Beroš 2013, 475; Britvić Vetma 2012, 402). The complexity of each individual matter that requires serious preparation before reaching a legislative decision was thereby neglected, as was the necessary competence of the administrative judges in various administrative areas. The notion of a model dispute attracted much attention from the scientific public. It was considered a novelty in the Croatian administrative dispute and was introduced with the aim of unifying judicial practice. The main purpose of the model dispute is to expedite disputes, which greatly resembles the system of benchmarks characteristic of the Anglo-Saxon system. Some authors consider the notion to lead to numerous dilemmas and disputes, but also impasses within judicial practice (Đerđa and Šikić 2012, 55). Unfortunately, not one administrative matter has been resolved by applying the institution of the model dispute thus far.

In the course of the Croatian administrative justice reform, the new ADA was passed in 2010, introducing a mechanism for the legal protection of citizens - the appeal against the decisions of first-instance administrative courts. In the past, the right to appeal had either very limited admissibility or was completely excluded. ${ }^{21}$ The absence of the legal framework for the regulation of the institution of appeal within the system of administrative judicial protection drew heavy criticism. ${ }^{22}$ The

20 Having reformed both procedural and organisational processes, the two-instance administrative adjudication has been introduced in a way such that there are now four different first-instance administrative courts: in Zagreb, Rijeka, Split and Osijek, and in Zagreb there is also the High Administrative Court. The High Administrative Court acting as the first-instance court has the right to exceptionally reach a decision based on the opinions of five judges when it comes to determining the legitimacy of general acts and it is standardised in a separate, sixth section of the Act (Articles 83-88 of the ADA).

21 The overview of the development of administrative dispute revealed that in specific periods of time (1922-1939, 1952-1977), the Croatian administrative procedural law recognised the appeal as a regular legal remedy. Nevertheless, examining the regulations on administrative dispute in Croatia, we noticed that for a long period of time (before 1918 until 1922, 1939-1952, 1991-2010), no legal formulation of regular legal remedy was envisaged in the Croatian administrative dispute. Based on the Law on Regular Courts of 1977, the specialised Administrative Court of Croatia was established. The ADA of 1977 introduced a number of innovations in administrative adjudication. Amendments to the ADA of 1977 envisaged significant changes in terms of the organisation of the Judiciary in administrative disputes. The legal regulation of the complaint in an administrative dispute changed through the historical development of administrative justice. The legal regulation of appeal in fact depended on Croatia's being a component of one or the other country and its legal system. For more about the historical development of administrative dispute in Croatia see Medvedović 2002, 1-35.

22 The lack of legal regulation of ordinary legal remedy to the Administrative Court (1991-2010) was one of the reasons for the necessary intervention in the regulation of administrative court proceedings and one of the key assumptions of harmonisation of Croatian legislation with the acquis. 
2010 legislation introduced the provisions on the right to appeal that emphasise the limitation when it comes to the review of the lawfulness of first-instance administrative court decisions. In accordance with the 2010 legal resolution, the institution had a restrictive effect for the fear of long-term administrative court proceeding. An appeal could be filed only in case of the adoption of the reformation judgments of the administrative courts in a dispute of full jurisdiction. ${ }^{23}$ Such too firm "filter" caused ineffective court protection of citizens' rights within the administrative justice system. Consequently, it resulted in inconsistent court practices, failure of the appeal court to act accordingly, legal uncertainty and inequality among citizens. Thus, the constitutionally guaranteed right to appeal as well as the right of access to court were challenged. ${ }^{24}$ The 2014 amendment to the $\mathrm{ADA}^{25}$ reduced the restrictiveness in this context considerably. We support the last amendments to the ADA of 2014, which greatly change and improve the process and the legal status of the parties. ${ }^{26}$

One of the greatest problems of the Croatian legal system in general is that it does not resolve individual judicial and administrative matters within a reasonable time period. For administrative-judicial protection it is of the utmost relevance that it be complete, timely and efficient. The basic principles of the administrative dispute were standardised by the ADA so as to determine the obligation to institute oral, immediate and public disputes along with the efficiency principle and limiting the decision-making process to a reasonable time frame. In order to ensure that individual principles be applied, relatively short deadlines were set, during which the court and the parties are to deal with the matter in question. The novelties were first and foremost passed in order to increase the efficiency of the court, in particular its competence to establish facts in disputes and to reach verdicts. Another novelty contributing to a more efficient decision-making process ensured by the ADA is the reformation system. ${ }^{27}$ The former cassation system conflicts with the right to a decision within a reasonable period because the legal matter is returned to the administrative body for a decision. This then causes the dispute to become insufficient as the instrument protecting rights, i.e. ensuring the legitimacy of administrative work. By providing detailed and clear instructions as to what an individual lawsuit

23 Article 66, paragraph 2 of the ADA (OG RC No. 20/10, 143/12).

24 For more about the effectiveness of appeal in administrative dispute and the practice of the High Administrative Court of Croatia (by ADA 2012), see Đanić and Ofak 2014, 174-179.

25 OG No. 20/10, 143/12, 152/14.

26 According to the current ADA (OG RC No. 20/10, 143/12, 152/14), the appeal is allowed in all cases except those prescribed by Article 66a. It remains to be seen whether the amendments to the ADA proposed in 2014 would achieve the much-desired goal of increasing the efficiency of the system, thereby contributing to faster and better decision-making in all instances.

27 About bringing reformation judgements, see Article 58, paragraphs 1 and 3 of the ADA. 
should apply to, the parties can file correctly formed lawsuits ${ }^{28}$, which enable court protection to be applied sooner. Hence, less time will be wasted in correcting the irregularities in the lawsuit that are often the reason why courts are prevented from functioning properly.

A party is given the possibility to choose the manner of securing legal protection either by filing a complaint or a lawsuit after their original case has been denied; this presents the basis for legal protection against administrative silence in the Republic of Croatia, frequently referred to as a system of negative fiction (Šikić 2008b, 150 , see Table 3 ). When the administrative authority does not complete the AP by the determined deadline ( 30 or 60 days), the party is given the right to complain as if their case has been denied. Whether the party files a lawsuit or starts a new administrative dispute due to the former not being resolved, depends on the authority that was assigned to the first case, i.e. whether a first- or second-instance authority reached the decision. When filing a complaint in the event of administrative silence, the second-instance authority is obliged to investigate the reasons which led to the untimely decision by asking for written notification. However, there are no regulations determining when the notification should be asked for (unless there was no delay), nor which steps should be undertaken in the event the first-instance authority does not provide such notification. If the reason for such is deemed to be justified, the first-instance authority will be set a new deadline of no longer than 30 days; if the reasons for silence are, however, unjustified, the authority can either resolve the matter completely or ask for a resolution within 15 days from the firstinstance authority. The conclusion to be drawn is that not every silence is illegal. The second-instance authority has to make its resolution and deliver it to the party as soon as possible, no longer than 60 days from the day the complaint has been filed. It is important that second-instance authorities deal with the APs themselves in order to avoid stalling, which then causes damage to the party. The Croatian APA (OG RC No. 47/09) provides one exception to administrative silence, i.e. where the party's demands are presumed to be accepted ${ }^{29}$, if in accordance with other regula-

28 According to the data provided by the Ministry of Justice in 2012, there was a significant increase of $44.68 \%$ in the number of resolved cases, especially those heard by the High Administrative Court (HAC). In 2012, first-instance administrative courts received 12,011 cases $-4,936$ of them have been resolved so far, while 7,075 have not, meaning that they do not resolve as many cases as they receive. It takes on average 523 days to resolve a case (according to the CR indicator), whereas the HAC takes only 382 days. See the Statistical Overview for 2012, Ministry of Justice, Zagreb, May 2013, 33-35.

29 Article 102 of the APA. The rule is that the ADA uses the notion of a negative fiction to ensure the legal protection of the party in the case when the first-instance authority has either not reached or not delivered a decision and an appeal is legally acceptable. More in Šikić 2008a, 493-499. 
tions (as an example of a positive legal fiction). If, however, double silence occurs, the parties are entitled to start an administrative dispute. ${ }^{30}$

By filing a lawsuit ${ }^{31}$ one can, inter alia, demand that an individual decision be nullified; the same applies to a decision reached in an untimely manner. In these two cases, the party can at the same time demand that the court reach a reforming decision. The basic rule is that when the administrative court finds the individual decision to be either against the law or not reached within the prescribed time frame, it grants the plaintiff's demand and issues the decision itself. The law prescribes two exceptions to this rule. The first one is when the court cannot reach a decision because of the nature of the dispute, and the other is when the administrative authority gives its assessment. The court is obliged to form a verdict and thereby resolve the administrative matter (a full jurisdiction dispute), while at the same time it prevents the possibility of a "ping-pong" (or "yo-yo") effect between administrative courts and administrative authorities (see Table 3). This is of utter importance if it is taken into account that the average administrative dispute took three years and four months. ${ }^{32}$ Now that we have illustrated one of the possible scenarios a party could go through, there is another possibility: the court itself does not reach a decision within a reasonable time frame; so what do the parties do then to ensure legal protection? Since there are no regulations prescribing the time frame for the court to reach its decisions (they are only instructive), it is extremely important that the court reach its decisions within reasonable time. Another possibility involving the extraordinary legal remedies available within administrative disputes (but only after the ECtHR has reached its final decision), is to submit a proposal for renewed deciding (Article 76 of the ADA). However, the final and key role in the entire supervision process belongs to the Supreme Court of the Republic of Croatia, which every party doubting the legitimacy of the legal verdicts reached by the Administrative Court and High Administrative

30 According to the former system of administrative disputes (Articles 26 and 42, paragraph 5 of the ADA, OG RC No. 53/91, 9/92, 77/92), if the party has filed a complaint due to a double silence, the court could have either denied the complaint or accepted it with the obligation to determine the manner by which resolution is to be made or simply reach the decision itself. The matters were mostly returned to the relevant administrative procedure. The verdict is binding, which means that the authorities are bound by legal interpretations and remarks presented in the verdict. The direct consequences were high costs for the parties to procedure, violations of decision-making within a reasonable time and the stalling of the procedures.

31 Different deadlines have been regulated for each of these lawsuits, as a first example, the lawsuit is to be filed within 30 days from the issuance of the decision, and as the second example, at the earliest 8 days after the deadline for issuing a decision has passed (Article 24, paragraphs 1 and 2 , of the ADA).

32 The Supreme Court of the Republic of Croatia considers a four-year period for regular and a three-year period for urgent cases to be far too long to be considered a reasonable time limit. The reasonable time for reaching decisions in administrative matters is violated if they exceed three years. The results are supported by the fact that the courts are overburdened, which is, by the way, not seen as a justification by the European Court (for more, see Lukanović-Ivanišević in Koprić 2014, 152). 
Court can contact for advice. In conclusion, if all matters are taken into account, the novelties introduced by the ADA in order to ensure all the rights guaranteed by the ECHR have been referred to as positive. The principal advantage of the mentioned full jurisdiction dispute lies in the fact that it more clearly, quickly and thoroughly resolves the administrative matter (see also Table 3 ).

The Croatian system responsible for detecting and avoiding a violation of rights in the process of a trial has received severe but justified criticism from the ECtHR. ${ }^{33}$ The criticism is not to be interpreted as a punishment for the country, but rather as some form of guidelines (individual or general measures) to improve the legal system. Many violations of the ECHR have been indicated regarding mostly a violation of the reasonable period prescribed for APs and disputes. In the great majority of cases the right to a fair trial was violated (Stažnik in Koprić 2014, 124). The key problem arises when the moment marking the beginning of the period that is significant for a reasonable appraisal is not the moment at which the administrative dispute started, but when the complaint was filed within an AP (the moment when the "dispute" is actually formed in accordance with Article 6 of the ECHR). In 2007 this caused a significant change in the practice of the Constitutional Court ${ }^{34}$ of the Republic of Croatia as well as the obligation to harmonise practice with the expressed understandings of the ECtHR. This is considered a turning point towards enhancement of the efficiency of legal protection. The changes introduced by the $\mathrm{LC}^{35}$ have, however, a considerable influence on the regulation of the concept of a trial within reasonable time. The matter could cause confusion among the citizens who now have the possibility to seek legal protection by filing a constitutional complaint before the Constitutional Court and/or Supreme Court.

33 See verdicts Rajak v. Croatia (28 June 2001), Horvat v. Croatia (26 July 2001). In 2012, the court reached 463 verdicts, 20 of them in the area of administrative disputes.

34 Decision and Resolution of the Constitutional Court, No. U-III-4885/2005, 20 June 2007. The Constitutional Court considered the time of filing a lawsuit before the Administrative Court as the beginning of the deadline, which was against legal interpretations and ECtHR practice. It demonstrated that AP are repetitiously returned to administrative dispute procedures, which prolongs the deadlines beyond any reasonable time frame and is as such seen as a disadvantage of the former administrative and judicial administrative system. This was also applicable to administrative silence, which was correctable only by changing legal regulations and acts. See the ECtHR verdicts - Počuča v. Croatia (26 June 2006), Božić v. Croatia (29 June 2006), Vajagić v. Croatia (27 July 2006), Smoje v. Croatia (11 November 2007), and Štokalo et al. v. Croatia (16 October 2008).

35 The LC (OG RC No. 28/13, 33/15, 82/15) allows two new legal remedies: a) submitting a claim for legal protection in a trial within a reasonable time, b) a claim for adequate financial compensation. The claim is submitted to the court leading the trial. Should the matter not be resolved within the prescribed deadline, the party is entitled to submit a claim for adequate financial compensation due to overstepping the reasonable period for a judicial procedure to a higher-instance court within a period of six months. If a verdict is reached by the High Administrative Court, the party can ask for protection from the Croatian Supreme Court. This makes the Supreme Court of the Republic of Croatia the highest instance, thus replacing the Constitutional Court of the Republic of Croatia. See Articles 63-70 of the LC. 
The question remains whether or not the ECtHR will again bring this Croatian system into question. The background of many changes refers to a decrease in the number of court procedures, to unburdening the courts, to paying out financial compensation as an exception, and to limiting the amount of adequate financial compensation. Since the decision-making process is "lowered" to the court that at the same time is handling the procedure itself, and since it favours the strengthening of the position of an individual judge, one cannot agree that the goal is to change the law and conclude procedures within reasonable time. The ECtHR reached 23 verdicts in 2012 in relation to Croatia (3 verdicts - right to fair trial within reasonable time, 5 verdicts - excessive length of proceedings), 18 of which were in favour of the complainant, pointing to an increase in compensation payments. ${ }^{36}$ The most common problems of violation of conventional rights are related to various aspects of the right to a fair trial, and in many cases violations occur in proceedings before national judicial authorities (civil, criminal, administrative, constitutional proceedings). The number of cases involving citizens versus Croatia increased (in 2012) by $45 \%$, and in 2013 the increase was even more significant, reaching $78 \%$ (cf. Table 3 ). Such a huge increase in the number of cases regarding violation of the right to a trial within reasonable time indicates an alarming situation, one that must be dealt with seriously. One of the reasons lies, inter alia, in the reflection of Croatian reality and the lack of citizens' trust in unbiased and professional judicial processes. A further increase in cases before the ECtHR is expected; the latest verdicts support this statement. ${ }^{37}$ The meaning of ECtHR verdicts is not to influence the content of the national bodies' decisions but to ensure the observance and implementation of procedural guarantees and standards provided to the parties in the procedures.

36 According to The Report on the Republic of Croatia Office Representatives before the European Court of Human Rights (1 January 2012-31 December 2013), Zagreb: 2013, Croatia paid EUR 325,950 to its cit-ns as compensation (70\% more than in 2011).

37 Jaćimović v. Croatia (31 October 2013), Peruško v. Croatia (15 January 2013), Keko v. Croatia and Aleksić v. Croatia (5 December 2013) point out the procedural mistakes made by administrative bodies, the Administrative Court, the High Administrative Court, and the Constitutional Court. 


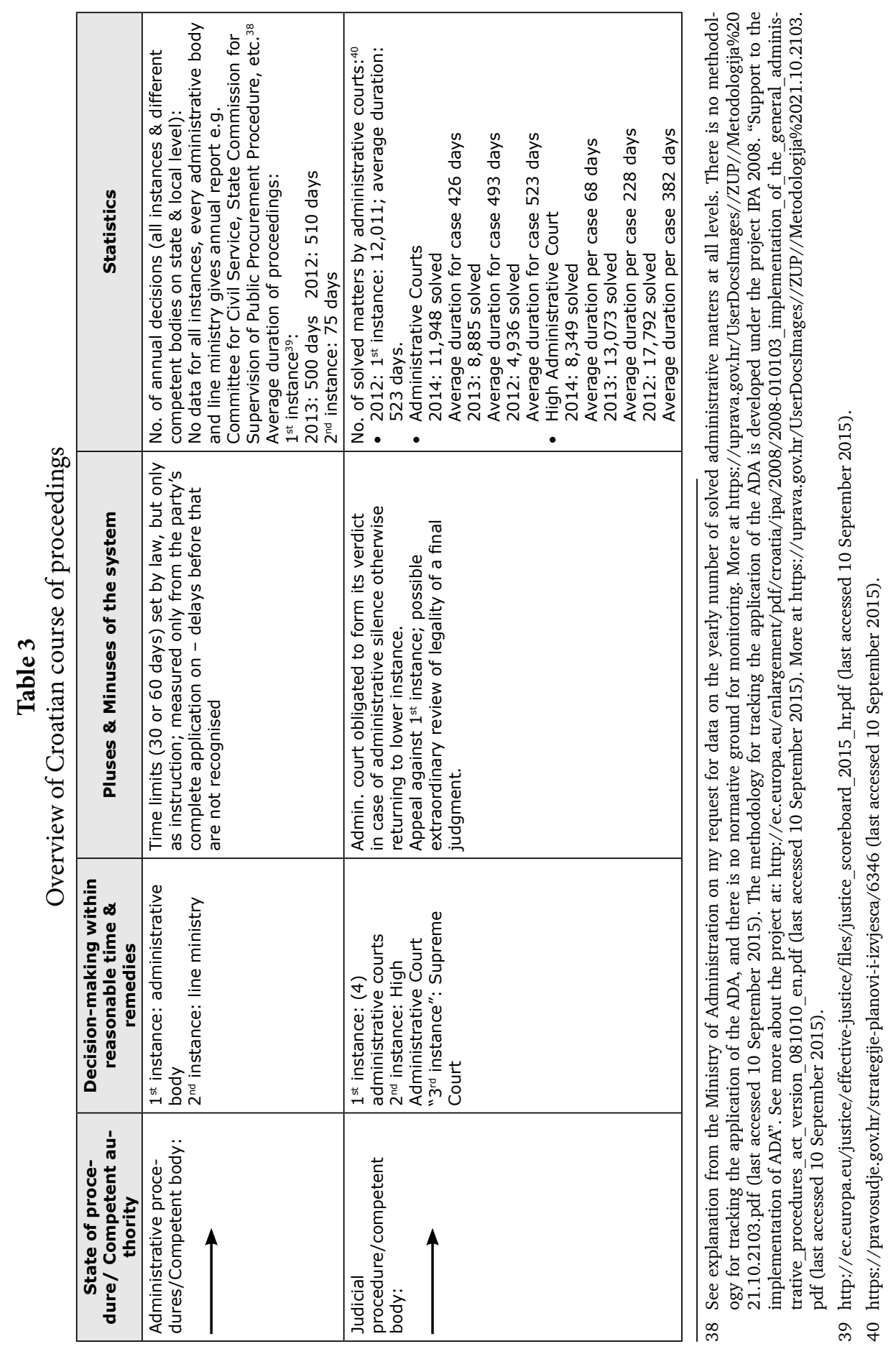




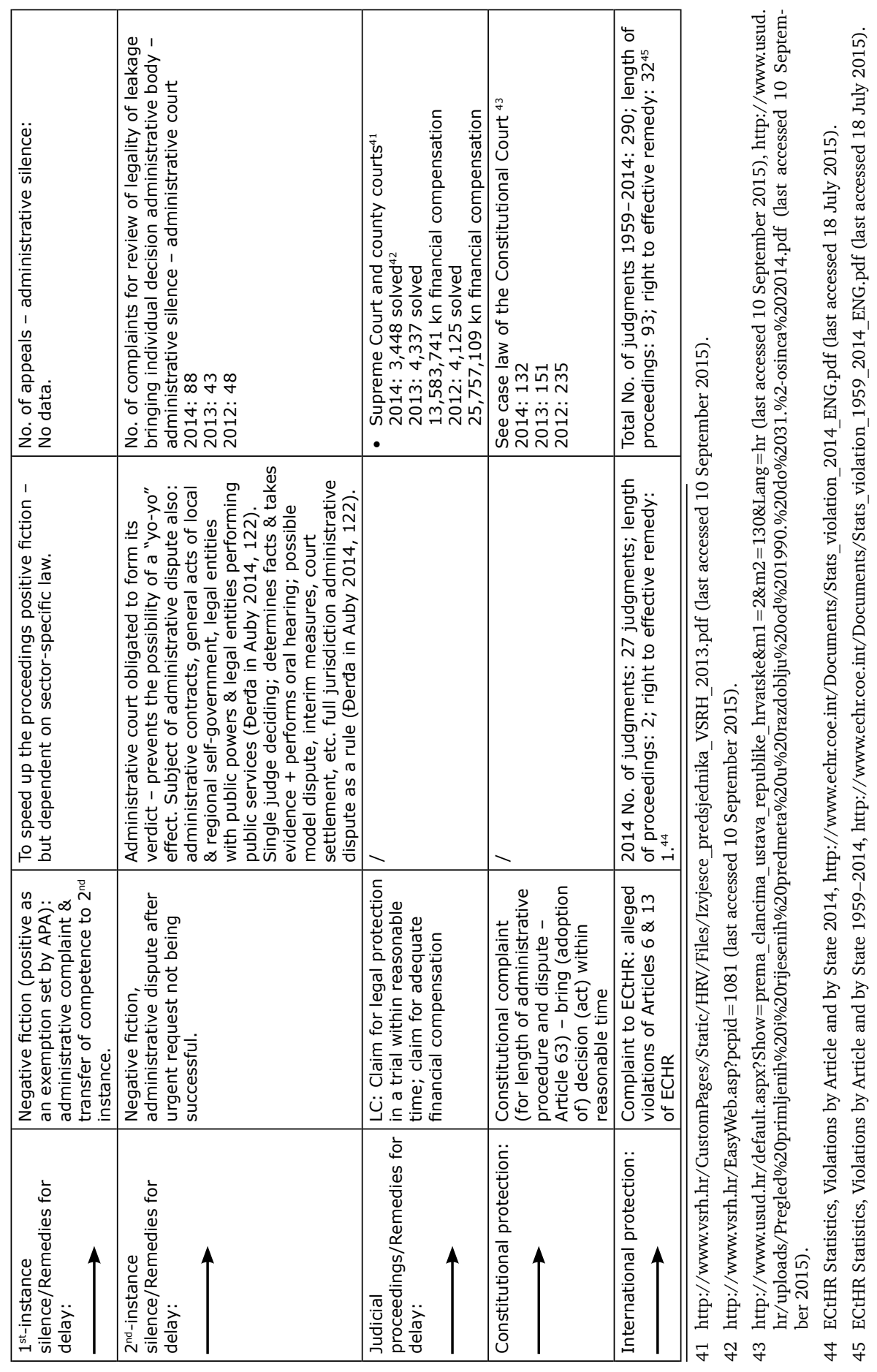




\section{Discussion and conclusion}

Effective administrative justice and AP, especially in terms of timely decisions, affect the entire society - in striving for legality, transparency and proportionality, within public administration and the business sector, in relation to NGOs, etc. (cf. Woehrling 2009). On average, the general time limit for AP as defined by the APA in selected EU Member States is approximately one month. ${ }^{46}$ However, in practice, their actual duration varies. For example, as stated in the 2013 Report of the European Commission for the Efficiency of Justice (CEPEJ), the average time required to receive all licences necessary for business in selected post-communist countries of Central and Eastern Europe ${ }^{47}$ was 30.6 days. ${ }^{48}$ Moreover, there are also differences in terms of judicial proceedings' duration when solving administrative law cases. For example in 2013, the disposition time ${ }^{49}$ of first-instance courts was on average 318 days $^{50}$ (cf. also Figure 1 below).

\section{Figure 1}

Resolving administrative cases

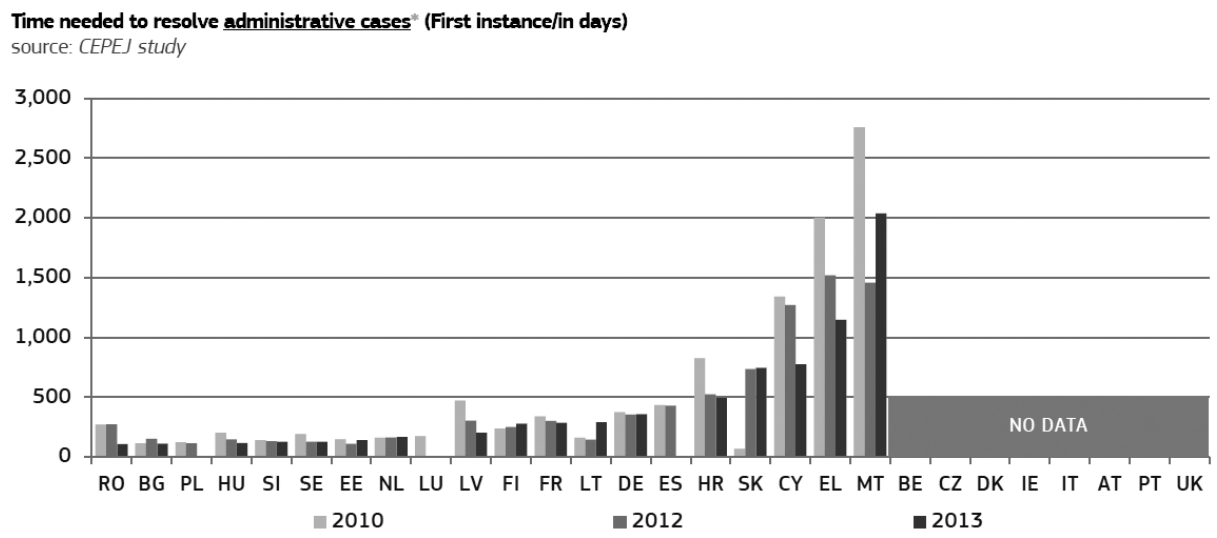

"Administrative law cases concern disputes between citizens and local, regional or national authorities, following the CEPEJ methodology. Administrative law cases are addressed by special administrative courts in some countries and handled by ordinary (civil) courts in others. Comparisons should be undertaken with care as some Member States reported changes in the methodology for data collection or categorisation (HU), a reorganisation of the administrative court system (HR) or made caveats on completeness of data that may not cover all Länder or all courts (DE, LU). Changes in incoming cases may allegedly explain variations in LT.

Source: The 2015 EU Justice Scoreboard 2015, 9

46 Statskontoret 2005, 34 (calculated from the data available in respective APAs setting time limits in days or months).

47 Data refer to Bulgaria, the Czech Republic, Hungary, Poland and Slovakia.

48 See Dubois et al. 2013, 659 (available data is for 2010).

49 The number of days necessary for a pending case to be solved in court (for detailed definition see CEPEJ Study on the functioning of judicial systems in the EU Member States 2015, 896-897).

50 CEPEJ Study on the functioning of judicial systems in the EU Member States 2015, 77. Since data for the Czech Republic and Poland were not available, we considered Bulgaria, Hungary and Slovakia in addition to Croatia and Slovenia. 
When looking into ways how each individual country achieves fundamental APA requirements (principles and rules) as derive from different guidelines and comparative research on APA content (see Cardona 2005, 1-16; Statskontoret 2005; Blomeyer and Sanz 2012), there are important differences among them, with some approaches being more effective than others. Some good examples of AP rules can be found in the Austrian (1991) and Estonian (2001) APA regulations. Austria was in fact one of the first countries to codify AP comprehensively already in 1925 and has served as a role model of Germanic tradition for the former Yugoslav territory until today. Likewise, German administrative law affected the Estonian APA (Pilving in Auby 2014, 162). Estonia regained its independence from the Soviet Union in 1991 and started to reform its legal system to establish a democratic, market-oriented state, pursuing within public-administration reforms also (post) New Public Management approaches (Savi and Metsma 2013, 8; Sorin 2015, 58). In this context, a short introduction is given hereafter to illustrate some of the AP institutions, which, we find, could be useful and reconsidered at the national level in respect of the effective regulation oriented towards timely decision-making. We focused on the following criteria of comparison: nature of acts included in the APA, flexible v. formalistic way of time-limits regulation, possible actions in case of administrative silence, judicial review of administrative acts and existence of alternative dispute resolution. Finally, we assess compliance of the Slovene and Croatian administrative-justice system with the Council of Europe recommendations.

In terms of the extent and nature of acts included in APA, we find the Estonian model, i.e. the regulation of all relevant acts (individual and general acts and public contracts) in one law, a good practice contributing to clear, uniform and transparent regulation, enabling legal certainty. Slovenia should indeed consider such in future amendments, while Croatia has already introduced public contracts in the APA, which we consider good progress. Unfortunately, the institution is not thoroughly defined by law, which prevents its actual and proper use in practice.

In terms of regulated time limits, the Estonian APA is flexible and sets a general rule to conduct AP without undue delay. In case of delay, the administrative authority must immediately issue a notice when the decision is expected and state the reasons for delay. The obligation of active performance is given to the administrative authority, and most of the burden is not on the parties, as in the Slovene and Croatian systems. We see such practice as a good example which promotes customer-oriented procedure. It contributes to positive communication and brings about solutions that are more satisfactory for all the involved participants. Contrary to the Estonian APA, the Austrian law defines a time limit of six months to issue administrative decisions. ${ }^{51}$ For the Slovene and Croatian administrative systems, the best way would probably be somewhere in between. We think that a completely

51 In case of delay, competence may be transferred to a superior authority on the party's request (for some matters at municipal level) if not directing to court immediately (Tour of Europe 2015, 7). If the delay was not caused mainly by the fault of the authority, the request is denied. 
flexible definition, more like a general principle, would not be appropriate; yet longer time limits should, as a general rule, be reconsidered. We suggest a time limit of three months as an APA rule.

In terms of review by higher instances, Estonia has a three-level court system and no mandatory challenge proceedings (Administrative Justice in Europe 2014, 12). The party can decide to file a challenge against an administrative act before the administrative authority that issued it or contest it directly before the administrative court as a first-instance court. The administrative authority competent to perform supervisory control adjudicates the challenge. If no such authority exists, then the one that issued the administrative act adjudicates on the matter. The result of these proceedings can also be contested before the administrative court. The court has the power to annul administrative acts, order their issuance, prohibit the making of the act; award compensations, etc. (Administrative Justice in Europe 2014, 10). Moreover, the parties can file an appeal against the first-instance judgments to circuit courts, which have administrative law chambers. Finally, the Supreme Court (Administrative Law Chamber) reviews court judgments within cassation proceedings.

On the other hand, Austria introduced important changes in administrative justice. Namely, as of January 2014, second-instance review is no longer performed by independent administrative chambers of the Länder (except for some matters at the municipal level). Instead, there are nine administrative courts of the provinces exercising judicial review over administrative decisions of state administrative authorities. Furthermore, judgments and decisions of first-instance courts can be contested before a supreme administrative court, but only when there is a legal issue of essential importance. Moreover, there is also a federal administrative court competent to review federal agencies' decisions and a federal fiscal court to review administrative decisions in tax matters. In case of failure to take decision, the latter can be challenged before administrative courts. If the administrative court does not act within the prescribed time limits (generally within six months), the applicant can file a claim at the Supreme Administrative Court, which will order the administrative court to decide within a certain period (Tour of Europe 2015, 8, 15-17). Administrative courts decide on the merits and have full powers to conduct investigations (Tour of Europe 2015, 22). The possibility of administrative courts to decide on the merits is very important and should also be promoted in the Slovene and Croatian systems, as this prevents the "yo-yo" effect and improves the procedures' efficiency, giving the parties a final decision within reasonable time. The current regulation indeed enables such decision-making, but in practice the authorities should actually make use of it. Moreover, in Slovenia and Croatia, the parties need to lodge a complaint before going to court. This typically means that there will be a two-instance AP, which could be followed also by two-instance judicial proceedings. In this respect, the new Austrian system (and similarly the Estonian one) 
could be considered somehow more effective in terms of the parties' possibility of earlier access to the court with a possible decision on the merits. ${ }^{52}$

Furthermore, we think that when the nature of the matter allows the use of alternative dispute resolutions (ADR), these should be introduced and used throughout all instances. For example, Austria foresees ADR in some specific areas, such as public procurement, environmental law and energy law (Tour of Europe 2015, 25). In Estonia, disputes can be settled by administrative authorities or their supervisory bodies in challenge proceedings (Administrative Justice in Europe 2014, 32-33). In Slovenia and Croatia, the APA and the ADA define settlement as one of the possible approaches. Furthermore, in Slovenia, there have been certain attempts to use mediation in environment disputes and in some building-permit procedures $;{ }^{53}$ however, more systemic approaches should be introduced by the actual regulation of other ADR institutions being applicable whenever the nature of the administrative matter enables it (e.g. taxes, inspection procedures, repayment of social benefits, etc.).

Finally, Slovenia and Croatia faced or still face the issue of the excessive length of procedures at the national level, although Slovenia seems to have made improvements while Croatia still copes with increasing systemic problems. Furthermore, Slovenia presents a significantly more stable and ECHR-compliant system than Croatia, which is a result of several factors. First, the regulation is more stable (there have been no ADA amendments in this respect since 2006 in Slovenia, but there have been constant recent changes in Croatia). Second, adversarial procedures are guaranteed in Slovenia by the subsidiary use of civil procedure, while such is lacking in Croatia. Third, the new Slovene ADA of 2006 introduced several efficiency institutions (such as limiting appeals). Finally, Slovenia is decreasing almost all traces of the former objective concept of an administrative dispute, while Croatia is even extending this type of judicial review to general administrative acts (even though preserving the test of their constitutionality still outside of the administrative dispute).

Nevertheless, Slovenia and Croatia share the systems applied in a majority of countries, both in terms of the organisation of the administrative judiciary and the scope of administrative dispute verdicts if administrative acts are found to be illegal. If we compare the normative landscape of the ADA in the respective countries in compliance with the Council of Europe recommendation on judicial review in administrative matters ( $\operatorname{Rec}(2004) 20)$, we can conclude the following:

- any violation (substantive law, procedural errors, or established facts) by different types of administrative acts is subject to an administrative dispute as an independent form of judicial review, establishing an effective separation of powers in practice;

52 However, in Austria, for some matters at the municipal level, there are still the independent administrative chambers of the Länder.

53 During AP, settlement between the parties with a conflict of interests is possible. Furthermore, settlement is envisaged by the ADA. However, mediation and other forms of ADR are not foreseen for administrative matters. 
- access to an impartial (in relation to the Executive) administrative court is guaranteed despite the obligatory prior exhaustion of administrative appeals before a lawsuit can be filed (differing completeness and finality of administrative decisions);

- fair trial adversarial guarantees are instituted by the ADA, such as: an oral hearing, the examination of all legal and factual issues, the public nature of the process, reasoning and being subject to a higher tribunal with two-tiered judicial review within the administrative dispute or by the constitutional court, etc.;

- the effectiveness of judicial review is normatively protected and increasing in practice by means of the possible (even if exceptional ${ }^{54}$ power of the court to decide on reforming decision (not only cassation), awarding costs, effective execution, provisional measures, etc.;

- different measures for ensuring faster procedures are introduced by national ADAs, such as time limits, allowing a lawsuit in the event of administrative silence, model procedures, non/suspensory effects, etc.;

- beside the ADA, there are other measures, legal and organisational, to further speed up timely final, and hence effective, decision-making in administrative matters.

As a consequence the several (even though rather significant) differences of the Slovene ADA compared to the Croatian ADA seem - if and when ECHR and other European standards are followed - of minor importance. We believe that even systemic violations, as found by the ECtHR in Slovene and Croatian cases, are more a result of the general political and administrative system of regulation itself, hence the overall culture and maturity of the transition processes. However (in particular in Croatia), changing the legislation regarding guarantees of a fair trial has caused the entire process to repeatedly move "back and forth". Hence, the manner in which domestic courts interpret the guarantee rights supported by the ECHR principles will determine the degree of their consistent and efficient application with the aim of attaining the efficient legal protection of citizens.

National APA and ADA should be regulated by acknowledging that they deal with the same life event of an individual party or plaintiff (see Figure 2). One would expect policy makers to regulate both procedures and laws hand in hand, from con-

54 Cassation, as the main alternative approach, is acceptable of course in selected cases (cf. Koprić 2014), such as administrative silence, if decision-making on the merits is not appropriate to the nature of the matter and/or there are discretionary public-administration competences in question (not allowing only one legal solution to the in-principle legality-bound administration). One must also be aware of the pros and cons of an in-principle required merit system, since it indeed accelerates the effective protection of the parties (no "yo-yo" effect, as in the cassation system) - if the authority is combined with broader reasons, but there are risks, such as the Judiciary assuming the competences of the Executive (the separation of powers principle) and the problem of the sufficient number and (specific) competences and/or organisation of administrative judges and courts. Cf. Article 65 of the Slovene ADA. 


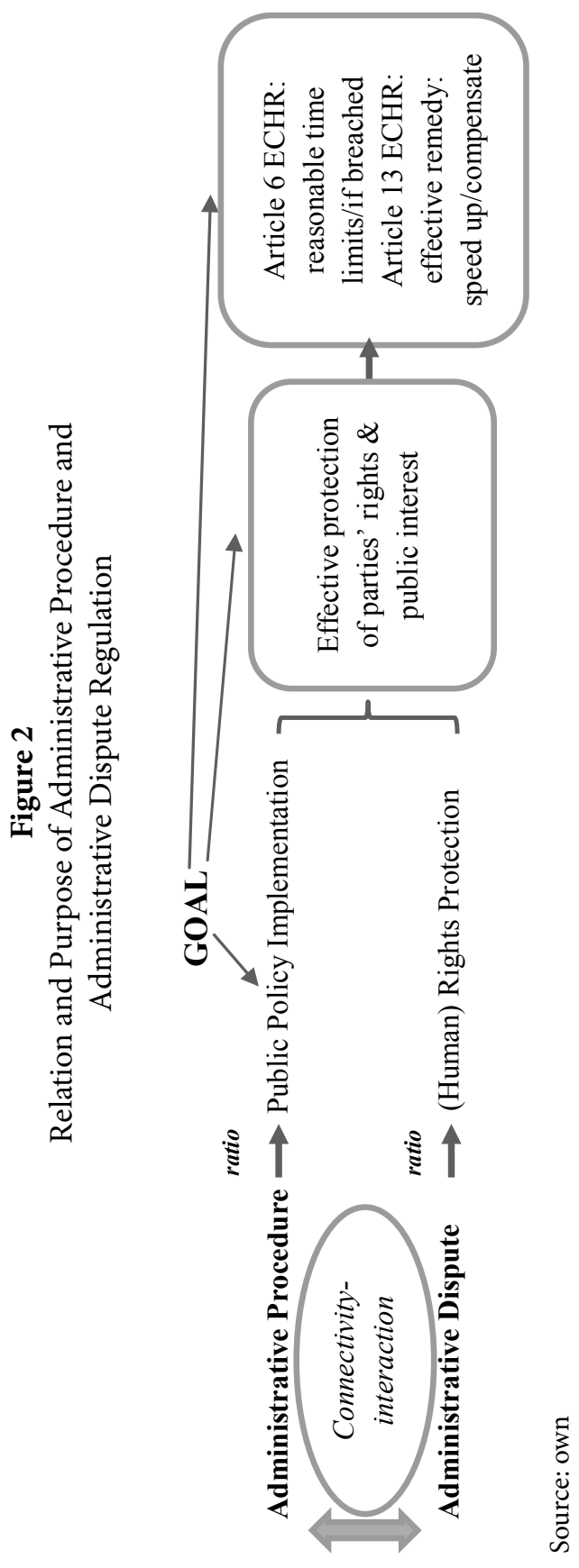


textual and also timing aspects. Unfortunately, this practice is hardly the case in Eastern Europe, as opposed to the (Western) EU..$^{55}$ Experience proves that part of the APA rules function so as to compensate for the lack of guarantees by the ADA - and even more so vice versa (Künnecke 2007, 152, Androjna and Kerševan 2006, 640 ). However, the relation between the APA and the ADA is supposed to interactively cover the different ratio of both procedures, namely AP pursuing primarily public/policy implementation and (a subjective) judicial review guaranteeing the protection of (human) right of parties against abuses of power by administrative authorities. Based on the mentioned discoveries and the analysed comparative approaches of Austria and Estonia, at least four issues in this respect deserve special attention, namely:

- the (broader) scope of AP and administrative-judicial disputes: all administrative acts can be challenged and regarding all possible violations/reasons, with a full investigation allowed;

- tiers of legal protection in administrative matters and further judicial review (all together, but at least a two-tiered administrative judiciary with an appeal (even if limited) within administrative disputes);

- courts' mandate to (not) act upon (illegal) administrative acts as a decision on the merits (reformatio mandate);

- a reasonable time limit also in administrative disputes and other forms of administrative justice, not purely or even primarily within the AP itself - and when a violation calls for it, proper individual compensation and systemic corrective measures are to be introduced.

Finally, if no systemic changes are introduced, but only minor legal amendments, as thus far in most Eastern European countries, one can only speak of the window dressing of good administration in order to please international observers. It is only all the aspects mentioned, taken together, that can significantly contribute to a systemic judicial review and finally to a state governed by the rule of law, as we all strive for.

\section{References}

Administrative Justice in Europe. 2014. Report for Estonia. Available at http://www. aca-europe.eu/index.php/en/tour-d-europe-en (last accessed 9 March 2016).

55 Cf. Stažnik in Koprić 2014, 123-133, vs. Künnecke 2007, 145-154. The latter work analyses guaranteeing a firmer completeness of administrative acts, for instance in Germany, within AP by broadening possible challenges of administrative acts before the courts. On principles and standards of quality regulation, cf. also Virant and Kovač 2010. 
Androjna, Vilko and Erik Kerševan. 2006. Upravno procesno pravo: upravni postopek in upravni spor [Administrative Procedural Law: The administrative procedure and administrative dispute]. Ljubljana: GV Založba.

Auburn, Jonathan, Jonathan Moffett and Andrew Sharland. 2013. Judicial Review> Principles and Procedures. Oxford: Oxford University Press.

Auby, Jean-Bernard (ed.). 2014. Codification of Administrative Procedure. Bruxelles: Bruylant.

Blomeyer and Sanz. 2012. "European Added Value Assessment on a Law of Administrative Procedure of the European Union, Annex III, Aspects Relating to the Efficiency of the EU Administration." EAVA 1/2012, III-1-III-96. Available at http://www.europarl.europa.eu/RegData/etudes/etudes/join/2012/494457/ IPOL-JOIN_ET(2012)494457(ANN03)_EN.pdf (last accessed 14 September 2015).

Britvić Vetma, Bosiljka. 2012. "Europska konvencija za zaštitu ljudskih prava (čl. 6.) i Zakon o upravnim sporovima iz 2010" [European Convention for the Protection of Human Rights (Art. 6.) and the Administrative Disputes Act of 2010]. Zbornik Pravnog fakulteta u Splitu 49(2), 395-410.

Cardona, Francisco. 2005. "Checklist for general law on administrative procedures." SIGMA. Available at http://www.sigmaweb.org/publicationsdocuments/37890936.pdf (last accessed 1 April 2016).

Đanić, Ana and Lana Ofak. 2014. "Djelotvornost žalbe u upravnom sporu kao jedno od temeljnih instituta zaštite ljudskih prava" [Effectiveness of Appeal in Administrative Dispute as one of the Institutes for Protection of Human Rights]. Pravni vjesnik 30(2), 167-183.

Đerđa, Dario and Marko Šikić. 2012. Komentar Zakona o upravnim sporovima [Commentary on the Administrative Disputes Act]. Zagreb: Novi informator.

Dubois, Eric, Christel Schurrer and Marco Velicogna. 2013. The Functioning of Judicial Systems and the Situation of the Economy in the European Union Member States, Compiled Report. Strasbourg: CEPEJ.

European Court of Human Rights Case Law, HUDOC. Available at http://hudoc. echr.coe.int/ (last accessed 15 January 2015).

Galligan, Denis J., Richard H. Langan II and Constance S. Nicandrou. 1998. Administrative Justice in the New European Democracies: Case Studies of Administrative Law and Process in Bulgaria, Estonia, Hungary, Poland and Ukraine. Oxford: Open Society Institute, Constitutional and Legislative Policy Institute and the Centre for Socio-Legal Studies, University of Oxford. 
Grafenauer, Božo and Janez Breznik. 2009. Upravno pravo: procesni del [Administrative Law: Procedural section]^. Ljubljana: Gospodarski vestnik.

Koprić, Ivan. 2006. "Upravno sudovanje u svjetlu prilagodbe standardima EU-a" [Administrative adjudication in light of adjustments to EU standards]. In Jakša Barbić (ed.). Reforma upravnog sudstva i upravnog postupanja [Reform of administrative courts and administrative procedures]. Zagreb: Hrvatska akademija znanosti i umjetnosti (HAZU), 58-63.

Koprić, Ivan (ed.). 2014. Europeizacija upravnog sudovanja [The Europeanisation of administrative adjudication]. Zagreb: Institut za javnu upravu.

Kovač, Polonca. 2012. "Fighting Administrative Silence in European and Slovene Law and Practice." In Dacian C. Dragoş, François Lafarge and Paulien Willemsen (eds). Permanent Study Group: Law and Public Administration: Proceedings/33 $3^{\text {rd }}$ Annual Conference of the European Group for Public Administration. Bucharest: Economică, 79-106.

Künnecke, Martina. 2007. Tradition and Change in Administrative Law: An AngloGerman Comparison. Berlin, New York: Springer.

Medvedović, Dragan. 2002. "Upravno sudstvo u Hrvatskoj: prilog za povijesni pregled" [The Administrative Judiciary in Croatia: Contribution to a historic overview]. In Marija Kriletić (ed.). Zbornik odluka Upravnog suda Republike Hrvatske 1977. -2002. Zagreb: Narodne novine, 1-35.

Omejec, Jasna. 2006. "Prilog reformi upravnog spora-odnosi između Upravnog i Ustavnog sudovanja u Republici Hrvatskoj" [Contribution to the reform of administrative dispute-relationships between administrative and constitutional adjudication in the Republic of Croatia]. In Marica Kuzmić and Ante Šumelj (eds). Upravno pravo i upravni postupak u praksi - aktualna pitanja $i$ problemi [Administrative law and administrative procedure in practice - current questions and problems]. Zagreb: Inženjerski biro, 8-22.

"Reforma sustava upravnog sudovanja u Hrvatskoj" [Reform of the system of administrative adjudication in Croatia]. 2008. Hrvatska i komparativna javna uprava 8(3), 567-586.

Rostaš-Beroš, Lidija. 2013. "Dileme u primjeni novog Zakonu o upravnim sporovima" [Dilemmas in the application of the new Administrative Disputes Act]. Zbornik Pravnog fakulteta u Splitu 50(2), 473-481.

Savi, Riin and Merlilin Metsma. 2013. Public Sector Reform in Estonia: Views and Experiences from Senior Executives. Country Report as part of the COCOPS Research Project. Available at http://www.cocops.eu/wp-content/uploads/2013/06/Estonia_WP3-Country-Report.pdf (last accessed 24 February 2016). 
Sever, Tina, Vedran Đulabić and Polonca Kovač. 2015. "Optimization of Administrative Capacity and Procedures of Constructing Permitting in Slovenia and Croatia." Paper presented at NISPAcee conference: Insourcing and/or Outsourcing: How do they Contribute to the Public Administration Reform?21-23 May 2015, Tbilisi, Georgia.

Sever, Tina, Iztok Rakar and Polonca Kovač. 2014. "Protecting Human Rights through Fundamental Principles of Administrative Procedures in Eastern Europe." DANUBE, Law and Economics Review 5(4), 249-275.

Sorin, Dan. 2015. "The New Public Management is not that Bad after all: Evidence from Estonia, Hungary and Romania." Transylvanian Review of Administrative Sciences 44 E, 57-73.

Statskontoret. 2005. "Principles of Good Administration in the Member States of the European Union." Available at http://www.statskontoret.se/upload/Publikationer/2005/200504.pdf (last accessed 23 January 2015).

Study on the Functioning of Judicial Systems in the EU Member States, Facts and Figures from the CEPEJ questionnaires 2010-2012-2013, CEPEJ(2014)17final (v2.0 - 16 February 2015).

Šikić, Marko. 2008a. "Pitanja uređenja i primjene pravne zaštite od šutnje uprave u Republici Hrvatskoj" [Questions on the planning and implementation of the legal protection of administrative silence in Croatia]. Zbornik Pravnog fakulteta u Rijeci 29(1), 491-521.

Šikić, Marko. 2008b. "Primjena pravnih fikcija u institutu zaštite građana od šutnje uprave" [The application of the legal fiction of the institute of the protection of citizens regarding administrative silence]. Zbornik Pravnog fakulteta u Splitu 45(1), 149-174.

Šikić, Marko. 2009. "Pravo na suđenje u razumnom roku u postupcima pred Upravnim sudom Republike Hrvatske" [The right to a trial within reasonable time in proceedings before the Administrative Court of the Republic of Croatia]. Zbornik Pravnog fakulteta u Rijeci 30(1), 333-372.

2015 EU Justice Scoreboard, Communication from the Commission to the European Parliament, the Council, the European Central Bank, the European Economic and Social Committee and the Committee of the Regions COM(2015) 116 final, European Commission, Directorate-General for Justice.

Tour of Europe, Contribution of Austria (as of 05/11/2015). Available at http:// www.aca-europe.eu/en/eurtour/i/countries/austria/austria_en.pdf (last accessed 25 February 2016).

Virant, Grega and Polonca Kovač. 2010. "Reducing Administrative Burdens as Part of the 'Better Regulation' Programme: The Case of Slovenia." Lex localis 8(4), 369-390. 
Venice Commission - European Commission for Democracy through Law. 2011. "Stocktaking on the Notions of 'Good Governance' and 'Good Administration', Study No. 470/2008, CDL-AD(2001)009". Available at http://www. eods.eu/library/VC.Stocktaking\%20On\%20The $\% 20$ Notions\%20Of\%20 \%E2\%80\%9CGood\%20Governance\%E2\%80\%9D\%20.pdf (last accessed 2 June 2016).

Woehrling, Jean-Marie. 2009. "Protecting Legality: Public Administration and Judiciary in EU Countries, How to Conciliate Executive Accountability and Judicial Review?" Paper presented at the Conference on Public Administration Reform and European Integration, 26-27 March 2009, Budva, Montenegro. http://www.sigmaweb.org/publications/42755351.pdf (last accessed 20 February 2016).

Woehrling, Jean-Marie. 2014. "Javna uprava i upravno sudovanje u zemljama Europske unije: kako pomiriti odgovornost izvršne vlasti i sudski nadzor uprave" [Public Administration and Administrative Justice in EU Countries: How to Harmonise Executive Authority Responsibility and Judicial Control of Administration]. In Ivan Koprić (ed.). Europeizacija upravnog sudovanja [The Europeanisation of Administrative Adjudication]. Zagreb: Institut za javnu upravu, 21-34. 